\title{
Isolation and Screening of Beneficial Endophytic Bacteria from Rice Grown under Coastal Saline Soils
}

\author{
S. Parvathapriya ${ }^{1}$, R. ThamizhVendan ${ }^{1 *}$, R. Subhashini ${ }^{1}$, \\ S. Thiruvudai Nambi ${ }^{2}$ and R. Renuka ${ }^{3}$
}

${ }^{1}$ Department of Agricultural Microbiology, ${ }^{2}$ Department of Plant Pathology, ${ }^{3}$ Department of Biotechnology, Agricultural College and Research Institute, Tamil Nadu Agricultural University, Madurai, India

*Corresponding author

\section{A B S T R A C T}

Keywords

Beneficial

Endophytic

Bacteria, Coastal

Saline Soils

Article Info

Accepted:

18 December 2020

Available Online:

10 January 2021
Salinity causes disturbance in symbiotic performance of plant and increases susceptibility of plants to soil-borne pathogens. Endophytic bacteria which are associated with their host plants have a beneficial effect for many different plant species and are determinant of cross-tolerance to biotic and abiotic stresses in plants. To maintain the growth and development of crops in saline condition, plant growth promoting rhizobacteria (PGPR) were isolated, and detected their plant growth promoting (PGP) potential under salt stress was investigated. In this study, fifteen endophytic bacteria were isolated from aerial parts of the rice which were grown in different regions of coastal soils. It was concluded that isolates $\mathrm{Ri} 4$ and $\mathrm{Ri} 12$ exhibited higher IAA production, isolates $\mathrm{Ri} 4$ and $\mathrm{Ri} 5$ showed better solubilization in phosphorous, $\mathrm{Ri} 3$ and $\mathrm{Ri} 4$ showed better solubilization of potassium. The result of this study can be used for further investigation in enhancing crop production and maintaining soil health in coastal saline soil environment.

\section{Introduction}

Rice (Oryza sativa) is one of the major staple food crops consumed globally and its production is highly affected by salinity. In India, nearly 9.38 million ha area is occupied by salt -affected soils out of which 5.5 million ha are saline (including coastal regions). Better management practices are needed to improve the productivity and quality of such low productive salty soils. Under the saline conditions the growth and development of rice are reduced because of the salinity- induced changes in metabolism and acidification of apoplast which affects the turgor pressure of cell (Munns and Tester, 2008). In plants, the effect of salinity leading to inhibition of germination, difficulties in crop area establishment, leaf area development, decrease in dry matter production, delay in seed set and also even sterility can occur (Khatun and Flowers., 1995).

Endophytes are the group of microorganisms that colonize the internal tissues of plants 
either by symbiotically or in a mutualistic relationship (Dudeja et al., 2012). However some of the endophytic bacteria exert several beneficial effect on host plants, such as stimulation of plant growth, nitrogen fixation, secretion of plant growth regulators (eg: IAA, phosphate solubilization activity)and induction of resistance to plant pathogens (Hung et al., 2004).Osmotic adjustment, stomatal regulation, modification of root morphology, enhance uptake of minerals and alteration of nitrogen accumulation and metabolism are some of the other effects of endophytes infection on the host plants (Zinniel et al., 2008, Stoltzfus et al.,1997). Various researchers reported that bacteria isolated from saline environment are more likely to withstand salt stress. The present investigation was carried out to isolate and screen the beneficial endophytic bacteria from rice (Oryza sativa) which are cultivated in coastal saline soil regions of Tamil Nadu.

\section{Materials and Methods}

\section{Sample collection}

The samples (rice crop) were collected from different coastal regions of Tamil Nadu(Cuddalore, Puducherry, Karaikal, Nagapattinam, Ramanathapuram). The samples were asymptomatic and healthy. The sterile plastic bags were used to collect all the samples and transported to the laboratory aseptically. The pre-treatment/ surface sterilization and isolation of endophytic bacteria from the collected samples were carried out according to the method described bySunet al.,(2006) with some modification.

\section{Surface sterilization}

Fresh leaf sample were washed in running tap water and surface disinfection were carried out in stepwise washing in $70 \%$ ethanol for 5min, $2 \%$ sodium hypochlorite solution for
$1 \mathrm{~min}, 70 \%$ ethanol for $30 \mathrm{sec}$ and followed by two rinses of sterile water and samples were dried Araujo et al., (2002). To conform whether surface sterilization was done properly, the sterilized leaf samples were imprinted in LB media or the aliquot of sterile water used in final rinse were inoculated into sterile LB broth to examine growth for overnight at $37^{\circ} \mathrm{C}$, ifno growth were observed then the disinfection process is successful.

\section{Isolation of endophytic bacteria}

After pretreatment, the samples were cut into small pieces and crushed in sterile water using pestle and mortar. About $1 \mathrm{ml}$ of crushed leaf sample was serially diluted up to $10^{-6}$ dilution and $0.1 \mathrm{ml}$ of aliquot from $10^{-5}$ and $10^{-6}$ were spread on sterile petri-plate containing LB media using sterilized glass rod. All the plates were incubated at $37^{\circ} \mathrm{C}$ for 5 days and observations were recorded regularly in order to recover maximum amount of colonies. After incubation, morphologically different isolates were streaked on petri-plate containing LB media and incubated it for 3-5 days at $37^{\circ} \mathrm{C}$.

\section{Morphological and biochemical characterization of endophytic bacterial isolates}

Classical gram staining method was used to determined cell morphology (Bathlomew, 1962). Biochemical test for citrate utilization, starch hydrolysis, indole test, methyl red and voges-proskauer were carried out according to the procedure described by Cappuccino and Sherman (2002).

\section{Screening for indole acetic acid producing activity}

Indole acetic acid production (Glickmann and Dessaux 1995) was examined colorimetrically using Salkowski'sreagent $\left(1 \mathrm{ml}\right.$ of $0.5 \mathrm{M} \mathrm{FeCl}_{3}$ 
in $49 \mathrm{ml}$ of $35 \%$ perchloric acid).To measure IAA qualitatively, isolated strains were aseptically cultured in respective broth containing $100 \mu \mathrm{g}$ L-tryptophan per $\mathrm{ml}$ and incubated at $37^{\circ} \mathrm{C}$ for 7 days.

After incubation period, the grown isolates were centrifuged at $10,000 \mathrm{rpm}$ for 20 minutes, $1 \mathrm{ml}$ of supernatant were mixed with two $\mathrm{ml}$ of Salkowski's reagent and one drop of ortho-phosphoric acid and incubated at room temperature for 25-30 min. Development of pink colour showed IAA production. For quantitative analysis, the absorbance of developed pink colour was measured at $530 \mathrm{~nm}$ and IAA concentrations were calculated by using IAA standard curve.

\section{Quantitative determination of phosphate solubilization activity}

Bacterial isolates were screened for their potential to solubilize insoluble calcium phosphate on Pikovskaya agar medium as described by Pikovskaya (1948).Fifteen endophytic bacterial strains were further evaluated quantitatively (Murphy and Riley, 1962), for their P-solubilizing ability in Pikovskaya's liquid medium in which $0.5 \%$ of tri-calcium were added as substrate. The strains were inoculated into $10 \mathrm{ml}$ of respective broth and incubated at $30^{\circ} \mathrm{C}$ for 7 days. Un-inoculated liquid broth was taken as control. After incubation period, the samples were centrifuged at $10,000 \mathrm{rpm}$ for $10 \mathrm{~min}$. One $\mathrm{ml}$ of supernatant from each sample were taken and $2 \mathrm{ml}$ of freshly prepared colour reagent ( $\mathrm{A}$ and $\mathrm{B}$ ) was added immediately and final volume were makeup to 6mlusing distilled water and incubated for $15 \mathrm{~min}$ to develop colour. The blue colour intensity was measured at $830 \mathrm{~nm}$ by UVspectrophotometer. $\mathrm{KH}_{2} \mathrm{PO}_{4}$ was used as standard and total amount of phosphate solubilization were expressed as total $\mathrm{P}$ release $\mathrm{mg} / \mathrm{L}$.

\section{Quantitative determination of $\mathrm{K}$ release activity}

Plates of modified Alexandrov's medium were supplemented withinsoluble form of potassium (mica) Aleksandrov et al., (1967). For quantitative analysis, the isolated strains were inoculated into $10 \mathrm{ml}$ of Aleksandrov's broth supplemented with insoluble form of $\mathrm{K}$ (Stanford et al., 1949) and culture flask were incubated at $30^{\circ} \mathrm{C}$ for 10 days. After incubation period, the samples were centrifuged at $6,000 \mathrm{rpm}$ for $10 \mathrm{~min}$ to remove insoluble potassium. Five $\mathrm{ml}$ of culture filtrate was added with $25 \mathrm{ml}$ of $1 \mathrm{~N}$ Ammonium acetate and the mixture samples were kept in mechanical shaker for $10 \mathrm{~min}$. After incubation the samples were filtered through Whatman No.1 filter paper and the collected filtrate were fed into flame photometer to determine the $\mathrm{K}$ content. The amount of potassium released were calculated using standard curve in which $\mathrm{KCl}$ used as standard. Un-inoculated broth was used as control.

\section{Statistical analysis}

The experiments were conducted in a completely randomized block design. The mean of three replicates were used to present the results. Standard deviation used to estimate the sample variability. Analysis of variance on the data at $\mathrm{CD}(0.05 \%)$

\section{Results and Discussion}

Endophytic bacterial isolates were isolated from rice crop that are grown in coastal saline regions of Tamil Nadu (Cuddalore, Karaikal, Nagapattinam,

Puducherry, Ramanathapuram) by using LB media. Some of the endophytic strains have been isolated from aerial tissues of four agronomic crops and from prairie plant species and also from other parts of the plants such as roots(Asraful 
et al.,2010), stems and seeds (Magnani et al., 2010), petioles, tuber tissues and flowers (Reiter and Sesssitsch, 2004) can also be used in isolation of endophytes.

Fifteen isolates were selected for further investigation based on their growth and morphology was shown in Table 1.Gayathriet al., 2010 isolated 36 bacterial strains based on different morphology from mangrove and salt marsh plants. In morphological characterization the endophytic bacterial isolates exhibit the diverse colony shape, colour, margins, elevation including round, circular to irregular colonies with regular and wavy margins.

Out of 15 isolates 6 were pigmented and 9 were non pigmented. Regarding the cell shape and gram staining, 7 gram negative bacilli, 1 gram negative cocci, 4 gram positive bacilli and 3 gram positive cocci were observed. Zinniel et al., (2002) reported an equal presence of both gram positive and negative bacteria in their study about endophytic bacteria isolation. Biochemical tests were carried out in which Ri 3, Ri 4, Ri 6, Ri 7, Ri 10, Ri 11 and $\mathrm{Ri} 12$ were positive in citrate utilization test, they produced blue colour in Simmon's citrate agar (Table 2).

Phosphate solubilization potential of the isolates was evaluated and the results indicated a significant variation among the isolates to solubilize different quantities of $\mathrm{PO}_{4}$ and release of $\mathrm{P}$ into the broth.

Maximum $\mathrm{P}$ release was noticed in $\mathrm{Ri} 5$ $\left(0.747 \pm 0.003 \mathrm{mg}^{-1}\right)$ followed by $\mathrm{Ri} 4$ $\left(0.590 \pm 0.004 \mathrm{mg} \mathrm{l}^{-1}\right)$. Minimum was reported with the isolate Ri $15\left(0.034 \pm 0.004 \mathrm{mg} \mathrm{l}^{-1}\right)$.

Table.1 Morphological characterization of endophytic bacteria isolated from aerial parts of rice crop grown in coastal saline soils

\begin{tabular}{|c|c|c|c|c|c|c|}
\hline \multirow{2}{*}{ ISOLATES } & GRAM & \multirow{2}{*}{ SHAPE } & \multicolumn{4}{c|}{ COLONY MORPHOLOGY } \\
\cline { 5 - 6 } & REACTION & & Form & Elevation & Margin & Colony \\
\hline Ri1 & gram negative & Bacilli & Circular & Raised & Entire & Translucent, slimy \\
\hline Ri2 & gram positive & Bacilli & Circular & Raised & Entire & Opaque \\
\hline Ri3 & gram negative & Bacilli & Circular & Flat & Entire & Colourless \\
\hline Ri4 & gram positive & Cocci & Irregular & Raised & Wavy & Dark brown \\
\hline Ri5 & gram negative & Bacilli & Irregular & Raised & Wavy & Light yellow \\
\hline Ri6 & gram positive & Cocci & Circular & Raised & Entire & Rough yellow \\
\hline Ri7 & gram negative & Cocci & Irregular & Umbonate & Entire & Opaque \\
\hline Ri8 & gram negative & Bacilli & Round & Flat & Entire & Transparent,slimy,glistering \\
\hline Ri9 & gram positive & Bacilli & Regular & Convex & Entire & Translucent \\
\hline Ri10 & gram positive & Cocci & Round & Convex & Entire & Yellow \\
\hline Ri11 & gram positive & Bacilli & Round & Raised & Entire & Opaque \\
\hline Ri12 & gram negative & Bacilli & Round & Flat & Entire & Opaque \\
\hline Ri13 & gram positive & Bacilli & Irregular & Undulate & Wavy & Colourless \\
\hline Ri14 & gram negative & Bacilli & Circular & Flat & Entire & Orange \\
\hline Ri15 & gram negative & Bacilli & Circular & Raised & Entire & Light brown \\
\hline
\end{tabular}


Table.2 Results of biochemical tests for selected endophytic bacteria from rice

\begin{tabular}{|c|c|c|c|c|c|c|}
\hline ISOLATES & MR & VP & CATALASE & $\begin{array}{c}\text { SIMMON } \\
\text { CITRATE } \\
\text { UTILIZATION }\end{array}$ & $\begin{array}{c}\text { STARCH } \\
\text { HYDROLYSIS }\end{array}$ & INDOLE \\
\hline Control & - & - & - & - & - & - \\
\hline Ri1 & + & + & + & - & - & - \\
\hline Ri2 & - & + & + & + & - & + \\
\hline Ri3 & + & - & - & + & + & + \\
\hline Ri4 & + & - & + & - & + & + \\
\hline Ri5 & - & + & - & - & + & + \\
\hline Ri6 & + & - & + & + & - & - \\
\hline Ri7 & + & - & + & + & - & - \\
\hline Ri8 & - & + & + & - & + & - \\
\hline Ri9 & + & + & + & - & + & + \\
\hline Ri10 & + & - & + & - & - & - \\
\hline Ri11 & + & + & - & + & - & - \\
\hline Ri12 & + & - & + & - & - & - \\
\hline Ri13 & - & - & - & + & + & + \\
\hline Ri14 & - & - & - & - & - & + \\
\hline Ri15 & + & - & - & - & - & + \\
\hline
\end{tabular}

++ highly positive, + positive, - negative

Table.3 IAA production, $\mathrm{P}$ solubilization and $\mathrm{K}$ solubilization activity of endophytic bacterial isolates

\begin{tabular}{|c|c|c|c|}
\hline $\begin{array}{l}\text { Endophytic bacterial } \\
\text { isolates }\end{array}$ & $\begin{array}{l}\text { Phosphorous } \\
\text { solubilization } \\
\left(\text { P release } \text { mg }^{-1}\right)\end{array}$ & $\begin{array}{l}\text { Potassium solubilization } \\
\left(\mathrm{K} \text { release } \mathrm{mg} \mathrm{l}^{-1}\right)\end{array}$ & $\begin{array}{l}\text { Indole Acetic Acid } \\
\left.\qquad(\mu \mathrm{g} \mathrm{ml})^{-1}\right)\end{array}$ \\
\hline Control & $0.013 \pm 0.002^{\circ}$ & $12.14 \pm 0.093^{\mathrm{k}}$ & $0.177 \pm 0.001^{j}$ \\
\hline Ri1 & $0.312 \pm 0.004^{\mathrm{g}}$ & $14.18 \pm 0.220^{\mathrm{g}}$ & $0.922 \pm 0.008^{\mathrm{e}}$ \\
\hline $\mathbf{R i} 2$ & $0.402 \pm 0.001^{\mathrm{f}}$ & $15.56 \pm 0.252^{c}$ & $1.110 \pm 0.009^{d}$ \\
\hline $\mathbf{R i 3}$ & $0.590 \pm 0.004^{b}$ & $20.14 \pm 0.407^{\mathrm{a}}$ & $1.112 \pm 0.002^{c}$ \\
\hline Ri4 & $0.747 \pm 0.003^{\mathrm{a}}$ & $19.45 \pm 0.165^{b}$ & $1.382 \pm 0.009^{\mathrm{a}}$ \\
\hline Ri5 & $0.489 \pm 0.005^{d}$ & $18.56 \pm 0.212^{c}$ & $1.229 \pm 0.003^{b}$ \\
\hline Ri6 & $0.236 \pm 0.003^{j}$ & $14.77 \pm 0.257^{f}$ & $0.541 \pm 0.006^{\mathrm{i}}$ \\
\hline Ri7 & $0.520 \pm 0.006^{\mathrm{c}}$ & $19.74 \pm 0.125^{\mathrm{a}}$ & $1.362 \pm 0.016^{\mathrm{a}}$ \\
\hline Ri8 & $0.215 \pm 0.003^{\mathrm{k}}$ & $13.19 \pm 0.218^{\mathrm{i}}$ & $0.726 \pm 0.011^{\mathrm{g}}$ \\
\hline Ri9 & $0.155 \pm 0.004^{1}$ & $15.15 \pm 0.128^{f}$ & $0.654 \pm 0.007^{\mathrm{h}}$ \\
\hline Ri10 & $0.448 \pm 0.004^{\mathrm{e}}$ & $12.89 \pm 0.016^{1}$ & $1.091 \pm 0.003^{d}$ \\
\hline Ri11 & $0.114 \pm 0.004^{\mathrm{m}}$ & $15.7 \pm 0.220 \mathrm{e}$ & $1.247 \pm 0.008^{b}$ \\
\hline Ri12 & $0.247 \pm 0.001^{i}$ & $16.05 \pm 0.352^{d}$ & $1.355 \pm 0.027^{\mathrm{a}}$ \\
\hline Ri13 & $0.401 \pm 0.002^{t}$ & $16.88 \pm 0.172^{\mathrm{h}}$ & $0.937 \pm 0.013^{\mathrm{e}}$ \\
\hline Ri14 & $0.034 \pm 0.001^{\mathrm{n}}$ & $13.57 \pm 0.247^{\mathrm{f}}$ & $0.564 \pm 0.004^{i}$ \\
\hline Ri15 & $0.28 \pm 0.005^{\mathrm{h}}$ & $14.94 \pm 0.127^{\mathrm{j}}$ & $0.219 \pm 0.001^{\mathrm{f}}$ \\
\hline Grand Mean & 0.324 & 15.791 & 1.001 \\
\hline SE.D & 0.006 & 0.384 & 0.019 \\
\hline $\mathrm{CD}(0.05)$ & 0.013 & 0.782 & 0.039 \\
\hline
\end{tabular}


The results were given in Table 3.Endophytic bacteria residing within plant tissues have been reported to promote the plant growth either directly or indirectly through the production of phytohormones and the improvement of nutritional status (Pandey et al., 2008). Huang et al., (2005) reported that most of the phosphate solubilizing endophytic bacteria belonging to Bacillus, Pseudomonas, Klebsiella and Acinetobacter were isolated from maize and rape plants. Thamizh Vendan et al., (2010) studied the endophytes of Gingseng plants and the endophytic isolates belonging to Bacillus cereus and Bacillus megaterium showed notable P-solubilization activity by detecting extracellular solubilization of precipitated tri-calcium phosphate with glucose as sole carbon. Phosphate solubilization by Bacillus sp from salt stressed environment had been observed (Sun et al., 2006) earlier. The amount of potash solubilized was assessed by using Flame photometer. Among the fifteen isolates, significantly higher release of $\mathrm{K}$ was observed in Ri3 $\left(20.14 \pm 0.407 \mathrm{mg} \mathrm{l}^{-1}\right)$ followed by $\mathrm{Ri} 4\left(19.45 \pm 0.165 \mathrm{mg} \mathrm{l}^{-1}\right)$. Minimum was reported in $\operatorname{Ri15}$ (12.89 \pm $0.016 \mathrm{mg} \mathrm{l}^{-1}$ ) and the results were tabulated in Table 3.Padma and Sukumar, (2015) reported that a considerably higher concentration of potassium solubilizing bacteria (KSB) are commonly found in the rhizosphere in comparison with non-rhizosphere soil.KSB are usually present in all soils and have been isolated from rhizosphere soil, nonrhizosphere soil, paddy soil (Bakhshandeh et al., 2017) and saline soil (Bhattacharya et al., 2016). IAA production was observed in 15 isolates of endophytic bacteria which were grown in LB broth supplemented with $0.1 \%$ tryptophan and the results were presented in Table 3. Most of the isolates exhibited significant variation in IAA production.In this study the isolate $\mathrm{Ri} 4$ produced higher quantity of IAA $\left(1.382 \pm 0.009 \mu \mathrm{g} \mathrm{ml}^{-1}\right)$ which was significantly higher than other isolates.
The minimum production of IAA was recorded in $\mathrm{Ri} 6$ which produced about $0.541 \pm 0.006 \mu \mathrm{g} \mathrm{ml} \mathrm{g}^{-1}$. Long et al.,(2008) reported the production of IAA by the endophytic isolates of Solanumnigrum. Endophytes have also been shown to promote plant growth by producing IAA (Mendes et $a l ., 2007)$, increases root size and distribution, resulting in greater absorption of nutrient from the soil(Li et al., 2008).

In this study, fifteen endophytic bacteria were isolated from aerial parts of the rice which were grown in different regions of coastal saline soils. It was concluded that isolate $\mathrm{Ri} 4$ and $\mathrm{Ri} 12$ exhibited higher IAA production, isolate $\mathrm{Ri} 4$ and $\mathrm{Ri} 5$ showed better solubilization in phosphorous, $\mathrm{Ri} 3$ and $\mathrm{Ri} 4$ showed better solubilization of potassium. These endophytic bacteria have the potential for phosphate and potassium solubilization and sufficient amount of IAA production. In future studies, these isolates could possibly be utilized for bio-remediation of salt affected soils for agricultural crop production.

\section{References}

Aleksandrov, V. G., R. N. Blagodyr, and I. P. Ilev."Liberation of phosphoric acid from apatite by silicate bacteria." Mikrobiol Z 29, no. 11 (1967): 1-1.

Araújo, Welington L., JoelmaMarcon, Walter Maccheroni, Jan Dirk van Elsas, Jim WL van Vuurde, and Joao LúcioAzevedo. "Diversity of endophytic bacterial populations and their interaction with Xylellafastidiosa in citrus plants." Applied and environmental microbiology 68, no. 10 (2002): 4906-4914.

Bakhshandeh, Esmaeil, Hemmatollah Pirdashti, and Khadijeh Shahsavarpour Lendeh. "Phosphate and potassiumsolubilizing bacteria effect on the growth of rice." Ecological 
Engineering 103 (2017): 164-169.

Bartholomew, James W. "Variables influencing results, and the precise definition of steps in Gram staining as a means of standardizing the results obtained." Stain Technology 37, no. 3 (1962): 139-155.

Bhattacharya, Sourish, PoojaBachani, Deepti Jain, Shailesh Kumar Patidar, and Sandhya Mishra. "Extraction of potassium from K-feldspar through potassium solubilization in the halophilicAcinetobacter soli (MTCC 5918) isolated from the experimental salt farm." International Journal of Mineral Processing 152 (2016): 53-57.

Cappuccino, J. G., and N. Sherman."Techniques for isolation of pure cultures.Cultural Characteristics of Microorganisms." Microbiology A Laboratory Manual, Pearson Education 6 (2002): 13-23.

Dudeja, S. S., RupaGiri, RanjanaSaini, PoojaSuneja-Madan, and Erika Kothe."Interaction of endophytic microbes with legumes." Journal of Basic Microbiology 52, no. 3 (2012): 248-260.

Gayathri, S., D. Saravanan, M. Radhakrishnan, R. Balagurunathan, and K. Kathiresan. "Bioprospecting potential of fast growing endophytic bacteria from leaves of mangrove and salt-marsh plant species." (2010).

Glickmann, Eric, and Yves Dessaux."A critical examination of the specificity of the salkowski reagent for indolic compounds produced by phytopathogenic bacteria." Applied and environmental microbiology 61, no. 2 (1995): 793-796.

Hung, Pham Quang, and K. Annapurna."Isolation and characterization of endophytic bacteria in soybean (Glycine sp.)." Omonrice 12 (2004): 92-101.
Islam, Shah MdAsraful, Renukaradhya K. Math, Jong Min Kim, MyoungGeun Yun, JiJoong Cho, Eun Jin Kim, Young Han Lee, and Han Dae Yun. "Effect of plant age on endophytic bacterial diversity of balloon flower (Platycodongrandiflorum) root and their antimicrobial activities." Current microbiology 61, no. 4 (2010): 346-356.

Khatun, Saleha, and T. J. Flowers. "Effects of salinity on seed set in rice." Plant, Cell \& Environment 18, no. 1 (1995): 61-67.

Li, Ji Hong, En Tao Wang, Wen Feng Chen, and Wen Xin Chen."Genetic diversity and potential for promotion of plant growth detected in nodule endophytic bacteria of soybean grown in Heilongjiang province of China." Soil Biology and Biochemistry 40, no. 1 (2008): 238-246.

Long, H. H., D. D. Schmidt, and I. T. Baldwin. "Native Bacterial Endophytes Promote Host Growth in a SpeciesSpecific Manner." Public Library of Science ONE 3: e2702 (2008).

Magnani, G. S., C. M. Didonet, L. M. Cruz, C. F. Picheth, F. O. Pedrosa, and E. M. Souza."Diversity of endophytic bacteria in Brazilian sugarcane." Genet $\mathrm{Mol}$ Res 9, no. 1 (2010): 250-258.

Mendes, Rodrigo, Aline A. Pizzirani-Kleiner, Welington L. Araujo, and Jos M. Raaijmakers. "Diversity of cultivated endophytic bacteria from sugarcane: genetic and biochemical characterization of Burkholderiacepacia complex isolates." Applied and environmental microbiology 73 , no. 22 (2007): 7259-7267.

Munns, Rana, and Mark Tester."Mechanisms of salinity tolerance." Annu. Rev. Plant Biol. 59 (2008): 651-681.

Murphy, J. A. M. E. S., and John P. Riley."A modified single solution method for the determination of phosphate in natural waters." Analyticachimicaacta 27 
(1962): 31-36.

Padma, S. D., and J. Sukumar."Response of mulberry to inoculation of potash mobilizing bacterial isolate and other bio-inoculants." Global J. Bio. Sci. Biotechnol 4 (2015): 50-53.

Pandey, Anita, Namrata Das, Bhavesh Kumar, K. Rinu, and PankajTrivedi. "Phosphate solubilization by Penicillium spp. isolated from soil samples of Indian Himalayan region." World Journal of Microbiology and Biotechnology 24, no. 1 (2008): $97-$ 102.

Pikovskaya, R. I. "Mobilization of phosphorus in soil in connection with vital activity of some microbial species." Mikrobiologiya 17 (1948): 362-370.

Sessitsch, Angela, Birgit Reiter, and Gabriele Berg."Endophytic bacterial communities of field-grown potato plants and their plant-growth-promoting and antagonistic abilities." Canadian journal of microbiology 50, no. 4 (2004): 239-249.

Stanford, George, and Leah English."Use of the flame photometer in rapid soil tests for K and Ca." Agronomy Journal 41, no. 9 (1949): 446-447.

Stoltzfus, J. R., R. M. P. P. So, P. P. Malarvithi, J. K. Ladha, and F. J. De
Bruijn."Isolation of endophytic bacteria from rice and assessment of their potential for supplying rice with biologically fixed nitrogen." Plant and Soil 194, no. 1-2 (1997): 25-36.

Sun, Lijun, Zhaoxin Lu, XiaomeiBie, Fengxia $\mathrm{Lu}$, and Shengyuan Yang."Isolation and characterization of a co-producer of fengycins and surfactins, endophytic Bacillus amyloliquefaciens ES-2, from ScutellariabaicalensisGeorgi." World

Journal of Microbiology and Biotechnology 22, no. 12 (2006): 12591266.

Vendan, RegupathyThamizh, Young Joon Yu, Sun Hee Lee, and Young $\mathrm{Ha}$ Rhee."Diversity of endophytic bacteria in ginseng and their potential for plant growth promotion." The Journal of Microbiology 48, no. 5 (2010): 559-565.

Zinniel, Denise K., Pat Lambrecht, N. Beth Harris, ZhengyuFeng, Daniel Kuczmarski, Phyllis Higley, Carol A. Ishimaru, AlahariArunakumari, Raúl G. Barletta, and Anne K. Vidaver. "Isolation and characterization of endophytic colonizing bacteria from agronomic crops and prairie plants." Applied and environmental microbiology 68, no. 5 (2002): 21982208.

\section{How to cite this article:}

Parvathapriya, S., R. Thamizh Vendan, R. Subhashini, S. Thiruvudai Nambi and Renuka, R.2021. Isolation and Screening of Beneficial Endophytic Bacteria from Rice Grown under Coastal Saline Soils. Int.J.Curr.Microbiol.App.Sci. 10(01): 2672-2679. doi: https://doi.org/10.20546/ijcmas.2021.1001.310 